\title{
UNDERSTANDING AMERICAN VALUES THROUGH EMERSON'S SELF-RELIANCE
}

\author{
Rudy \\ Universitas Prima Indonesia, Medan, Indonesia \\ email: rudyl@unprimdn.ac.id
}

\begin{abstract}
By conducting a library research, this study focused on the influence of one of the prominent figures in American romanticism, Ralph Waldo Emerson in shaping American Values. By applying the Hall's Theory of Representation as the method of analysis, this study intended to identify the role of Self-Reliance in American culture and the impact of Emerson's philosophy toward American life And now people all over the world had recognized his work Self-Reliance (1841) as the inspiration in many aspects of life. His hard work, ethical teaching and spirit had become the most important ideas in shaping independent American society. It was expected that the study may contribute to enrichment of cultural, social and literary theories. The result showed that through his literary works, Emerson had conveyed important messages to the world, and to the United States in particular, in terms of shaping identity and enriching American values.
\end{abstract}

Key words: American Romanticism, Independence, Spirit

\section{Introduction}

There was one of the main important men who has led America to a new change. Ralph Waldo Emerson may be known as the father of "Self-Reliance". His writings Self-Reliance (1841) brought him to the central of attention in America. One of the most widely known figures as well as the icon of the American Romanticism in the $19^{\text {th }}$ century was Ralph Waldo Emerson. He brought new vision to America that is 'individualism'. Born in 1803, Emerson was an educated layman who spent his time writing. This intelligent scholar graduated from Harvard Divinity School. He was basically inspired by
Wordsworth and Coleridge in his works. He was also a very hypercritical thinker. He even though deeply on how somebody should deal with himself. Born in Boston, 1803, Emerson was the most

influential icon at that time. He wrote persuasive, firm, critical and conceptual writings turned out to be the basic principle in American life. This outstanding leading figure expressed all his ideas in poems and prose. His foremost essay SelfReliance (1841) unavoidably gave inspirations to many American authors.

Since the subject discussed here was closely and obviously connected to a very fundamental concept, Self-Reliance. From 
what had been depicted historically, one of the characteristics of Romanticism that the writer focused was 'self' in the relation to nature and God This unshakeable way of thinking was the widely known and firmly applied in American life. This permanent basic principle essentially inspired the people in America. America was seen as a very free and powerful country. They were tough and independent people who rely on themselves. Thus, the writer was very excited to explore and analyze further on it.

This writing certainly focused on Emerson's most well-known essay SelfReliance and some of his beautiful sensible poems that truly inspired Americans in thoughts and the way of life. There were two main objectives of this study. It intended to identify the role of the idea of Self-Reliance in American life and to find out the impact of Emerson's philosophy in American Life. There must be several publications on Emerson's works (as explained in Literature Review), however, this study may offer another kind of perspective in understanding Emerson's Self-Reliance. Ralph Waldo Emerson in his main writings always insisted the importance of being conscious, independent, and realistic. It had definitely given a powerful impact to America. Emerson's works had a precious meaning which was also elaborated in this study.

\section{Literature Review}

There had been many discussions on Emerson's Self-Reliance, especially in journals. Most of the articles were concentrated on the criticism, for instance, Carbone II (2010), Cassidy (2013) Liang (2013), and Forsberg (2019). They generated different kinds of ideas on SelfReliance. However, those perspectives might seem different from this study. The idea of self-reliance may seem different if it was approached by another kind of theory and written by the person from another cultural background.

By focusing of what the essay represented and how the representations were interpreted by an academician with Asian backgrounds who had been learning American Studies, the discussion might bring about some ideas which could enrich as well as developed the cultural, social and literary theories.

\section{Research Method}

In order to write academically, there many references related to the discussion, which had been provided. Careful reading on the essay Self-Reliance was of course required. Some of the fundamental principles and ideas in the essay to the basic theory of American Romanticism were carefully examined. Then some relevant references were used to support the values found in the Self-Reliance in order to show the impact in American life.

The writer applied a library research on this study which he thought as the most effective method in analyzing literary works such as poems, prose, autobiography, bibliography etc. As Hariwijaya and Djaelani (2004) stated that library research was entirely used from the beginning to the end of a research. Most of the data needed in this study were accurate writings and information that completely obtained from the main reference and several relevant references. It took the writer quite long to read and search the authentic data and information. Hall's theory of representation was applied for analysis. Text such as essay, poems, or any literary works may be treated as a symbol which might represent something (Hall, 1997).

Some important materials dealing with the establishment of America and the period of romanticism had been provided 
in order to be used for analysis. The materials covered the basic idea of Emerson's, the relation to American life and romanticism and some of his literary works.

The paper presented contained some main sections, namely Introduction, The Background, The Analysis and Conclusion. Each part carries important discussions which were very closely related. The first section described the intention of the writer in choosing the topic, the research design and the purposes of the discussion. The second section broadly introduced and elaborated the center of the problem. The third part was the part of analyzing the findings to see the relation to the facts and realities. The Last part shown the conclusion of the whole discussion of the study.

\section{Result and Discussion}

Based on the analysis there were several primary points that shown the Emerson's Self-Reliance emphasized in the shaping of American values. Firstly, we needed to know that there was a strong connection between Emerson and his own work Self-Reliance which was one of the most important works in the era of American Romanticism.

The United States that we now known was a super power country. It was full of busy working people. They worked for their own lives and future. This great and restless nation was far different from what we see now. We might probably wondered what actually form this country and its cultural life particularly in Romanticism in $19^{\text {th }}$ century. There were a large number of changes in all aspects of life, political life, social and culture, economics, art and literature. It was closely related to the individuals. Emerson in his essay Self-Reliance (1841) described the spirit of God in us. His idea on selfreliance had absolutely attracted a lot of
Americans to trace a better way to live independently and prosperously.

Emerson's idea to American life Romanticism characteristics that seemed to be very firm and influential. This strong teaching lied on everybody's mind and would keep on inspiring the next generations. Romanticism marked the expansion of freedom in life of literature, particularly in the period of intelligence and art. It was first took place in Germany. The spirit of Romanticism was then spread to England, France, and even the other European countries. This brand new vision gave new thoughts and understanding to people about nature, life, and independence.

He believed that all of us were created by God to be courageous. Human beings were naturally given bravery to do everything. He believed that people had unbelievable power to do, to change and to fix in everyday life. Art was naturally the key to achieve the power. He expressed all his concepts tangibly in his fabulous literary works. In the relation to the religion, Emerson in his Self-Reliance has a very contradictive meaning. He tried to convey something important to people. He believed in God. He known that God had given something powerful that they did not realize. It had also become a great impact to the religious life and the discussion the secularism in America.

Emerson in his critical writings quoted by Pritchard (1956) stated that work of art was showed the creator's ability to picture sufficiently by the way he expressed and observed something. The explanation above could show that there was always a powerful value lies in literary works that could entirely alter someone's life. The relation between literary works and social reality was reciprocal. And this relation would then influence the development of the society. This completely made sense. 
American Romanticism began at the beginning of the $19^{\text {th }}$ century. This crucial movement (1820-1860) in America was centered in literature. Van Spanckeren in his book USA Literature in Brief (1995) obviously asserted that many romantic thinkers believed that art was not science. It was aesthetic and spiritual dimension of the nature, inspiration and metaphorical organic development. This was undoubtedly and intimately related to individuals, desire, emotion, freedom, religious values, and power of imagination.

Incredible Ralph Waldo Emerson contributed a lot of his beautiful writings that was tenderly emotional but strong. Most of his poems talk about life, the beauty of the nature and independence that reflect the expression his deepest feeling and thoughts about real life that people should understand and own. Besides Emerson, there was also another figure involved in this movement. He was the best friend of Emerson's, Henry David Thoreau. Thoreau's idea was not far different from Emerson's.

The truth was that, more and more people began to be sick of the unpleasant lives, boredom, pressure, authorities and force that came from certain people or organization. Emerson considered all of these as improper elements that needed to be buried. This movement affected every single aspect of life including art, literature, principles (ideas), and politics, etc. American Romanticism was precisely considered as the climax of the history of American literature. It later brought a great change to American literary works and people's daily principles since literature was the best media to reach their hearts and mind.

"Self and nature are the one" is the theory of Romanticism. Self-Reliance did not end to selfishness, but it was indeed a better way to open a new world. If someone united himself to the entire of human life, then he would have a moral duty to unbalanced social life and reduce human suffering. This concept of Romanticism commenced the variations of the use of the word "self" such as "selfcontrol", "self-express" and "self-help" etc. This complex principle wholly changed the previous perception about "self" as the previous generations defined as selfishness. This has actually paved a way to American people to learn to rely on themselves.

When people talked about American Romanticism which took place in 18201860 , there was a very gifted and critical thinker who was the pioneer of the Romanticism movement, Ralph Waldo Emerson. He also wrote poem and prose, particularly essays. This remarkably active and lively Emerson was considered as a man who carried a holy mission. He was accused since his ideas were against the teaching of Christianity. He once said, "To be a good priest you need to leave the church." His critical philosophy made him leaved the church for 30 years. He focused on the power and ability of an individual that naturally and emotionally created own ways of better lives. He also gave a speech written in the form of essay "The Divinity School Address" (1838).

AS Capper and Hollinger quoted in their book The American Intellectual Tradition (2001), Emerson wrote:

I look for the new teacher, that shall follow so far those shining laws, that he shall see them come full circle; shall see their rounding complete grace; shall see the world to be minor of the soul; shall see the identity of the law of gravitation with purity of heart; and shall show that the Ought, that Duty, is one thing with Science, with Beauty, and with Joy. 
Many people were totally confused with his doctrine as it was far different from the doctrine of Christianity. He desired a whole new life. Life which everybody could freely express something emotionally, naturally and blissfully without being obstructed or bounded by any other things such as religious teachings and social concepts, etc.

The concepts that Emerson offered was the inspirations of the nature. In nature nothing was arbitrary and isolated. $\mathrm{He}$ related things to the nature. Soul, individual, and art belong to the nature, so did the literature. He believed each poem had its own form as a part of its organism (Criticism in America). In the relation to the natural life, Emerson believed that creatures that had been created properly by God also had their own roles in life. Wild nature was a part of us. Animals were given instinct to survive and to count on themselves to live the nature. Science was another thing that absolutely people did not have to relate to their social lives, principles, beliefs and art. However, his principle thoughts were adopted by a lot of American people in order to learn and apply in all aspects of life, especially in art and literature. His thoughts on national needs and visions, personal experience, cosmic Over-Soul, and a set of doctrines on compensation were expressed in his first established literary works, Nature (1836).

The Norton Anthology of American Literature (1989) stated that Emerson was gradually developing a faith greater in individual moral sentiment than in revealed religion. This however led people to a different perception. It was then expanded through his Self-Reliance. Many philosophies in the era of American Romanticism expressed in his literary works entirely criticize the previous Neoclassic movement in art in the $18^{\text {th }}$ century that fully emphasized on ratio, balance and self-control. Emerson was against those Neo-classical elements in life and art in particular.

Emerson came to his idea on SelfDevelopment. This value was the main concentration of his essay The poet written in 1844. It reflected Self-Reliance as the basic method as well. It emphasized the importance of art as the main key to express for either individuals or society. There were still many essays which sounded the same and held the same goal and purpose. Then he came with another new works. Surprisingly, Millions of eyes rolled at him, when his outstanding works entitled Self-Reliance published.

This well-know and eyes-catching essay was written by Ralph Waldo Emerson in 1841. Among his literary works, this was the most foremost and extremely influential. "Self-Reliance" at that time was a brand new philosophy that surely gave a path to expand the Romanticism movement in America which relied on flexibility and intuition. In his masterpiece, he was certainly consistent with the birth of individualism. This contradictory essay was consciously written to protest against the previous way of thinking which centered on rational intelligence. Moreover, the movement of Romanticism in America could certainly fertilize the masterpiece "American Renaissance". As a result, the idea had contributed to the forming of American identity which was important to the United States. Emerson's Self-Reliance was not only concerned with how people should serve and contribute to the nation, it also related to a set of personal guiding principles for behaving (Liang, 2013). This perspective was also supported by Forsberg (2019) who emphasized that Emerson's works could be used to learn to behave and to build identity and to gain knowledge. 
Many literary critics said that American Romanticism was marked by the great works of Emerson's, Self-Reliance. The spirit of self-reliance had actually begun at the beginning of the American history. When people from the Old World to the New World, they tried very hard to survive and count on themselves to face the severe weather and wild life. They had actually entrusted themselves. If it was related to the Self-Reliance that Emerson points out, then it would definitely show the spirit of 'self'. Later, Emerson began to talk about it very vividly in his essay entitled Self-Reliance.

One of the critics, Matthew Arnold even said that Emerson's essay was one of the most important writings in the $19^{\text {th }}$ century. This meant that his essay had given an enormous affect to American Romanticism and American history. This was the climax of the period of Romanticism. It was one of the most important world's histories that had broadly changed people's visions, lives, ways of thinking and concepts.

The beauty of the nature, the power of emotions and imagination colored the American Romantic writings. Self-Reliance reflects all of Emerson's hard work and elaborates all his ideal beliefs on life. The writer of this paper had quoted some expressions or statements from selfReliance to be analyzed and discussed. They were needed in this academic writing in order to know the relation to American romanticism and American life. The fire of American Romanticism gave heat as a brand new hope and great expectation to face the truth that all people were born independently with courage, power and capability. Then we must not fear for doing anything according to our will and heart since nobody had authority on us.

Emerson emphasized that it was essential that someone be conscious of being himself. He believed that if someone just simply did what he intended to do, it would definitely give him delight. The writer quoted some remarkable sentences from Emerson's Self-Reliance "What I must do, is all that concerns me, not what the people think." He probably tried to say that we were the masters of ourselves, but not the masters of the others'. Thus, we were naturally told to do whatever deals with us only. This basic concept was certainly a pathway to the idea of Individualism. The word 'individualism' according to Emerson was very essential and meaningful. Emerson described the ideal thought of 'individualism' in the transcendentalism point of view. 'Individualism' would later play a very important role in shaping American character like the America we see today. There was a strong and powerful soul in each individual to hang on. To support the ides, the there were some expressions:

I will not hurt you and myself by hypocritical attentions. If you are true, but not in the same truth with me, cleave to your companions; I will seek my own. I do this not selfishly, but humbly and truly.

The quoted sentences above sound similar to the previous one. We could not make somebody accepted something which did not satisfy him. We all were independent to determine what we would deal with and what we must handle.

As an addition, the writer also quoted another impressively firm statement in self-Reliance "Do your work, and you shall reinforce yourself." In order to qualify yourself well, you must concentrate on yourself and do something properly as your courage and ability support you to do so. Emerson's Self-Reliance had widely inspired a lot authors from the $19^{\text {th }}$ century up to the present time in their works. Many writers even wrote the same 
thing to the readers. For instance, May, a modern writer in the $21^{\text {st }}$ century in his book Absolute Impact (2004) emphasized "Once we know our realm of potential excellence, we must unleash our power by placing our talents in a position from which they would not only continually develop but also yield the most impactful results." If we looked at the quotation above, we would find the similar idea as Emerson described in his works. Our power lied in ourselves. If we totally realized and seriously and courageously digged it deeper, then we could obtain the true life in ourselves. It must not have something to do with other persons for the power was ours and we just did the things concern with us.

Something must change. And the change took many aspects of life. In other words, Self-Reliance (1841) became a kind of revolution. It was written obviously, as the writer had quoted from Capper and Hollinger in their book The American Intellectual Tradition (2001):

It is easy too see that a greater selfreliance must work a revolution in all the offices and relation of men; in their religion; in their education; in their pursuits; their modes of living, their association; in their property; in their speculative views.

Another unavoidable and basic aspect found in Emerson's literary works was nature. This was indeed the common feature in Romantic literature. Again, the writer quoted from Self-Reliance "A true man belonged to no other time or place, but was the centre of things. Where he was, there was nature." We belonged to nature, then, we naturally should think emotionally and do whatever we considered right without being afraid of any obstructions or hindrances. Quoted from The American Intellectuals Tradition
(2001) "Nothing can bring you peace but yourself" was actually what Emerson meant in Self-Reliance.

In relation to the discussion of SelfReliance by Emerson, the writer of the paper had tried to make a list of attitudes suggested in Emerson's philosophy. This was done in order to make the readers saw obviously the basic ideas of SelfReliance and to simplify as well. Looked some of his concepts in Self-Reliance at the list below (The American Intellectual Tradition).

\begin{tabular}{|l|l|}
\hline \multicolumn{1}{|c|}{ To Do } & \multicolumn{1}{c|}{ Not To Do } \\
\hline $\begin{array}{l}\text { To believe your own } \\
\text { thought. }\end{array}$ & $\begin{array}{l}\text { Don't believe in } \\
\text { others' thought. }\end{array}$ \\
\hline $\begin{array}{l}\text { Be open and trust } \\
\text { yourself. }\end{array}$ & $\begin{array}{l}\text { Don't be narrow- } \\
\text { minded. }\end{array}$ \\
\hline $\begin{array}{l}\text { Do all that concerns } \\
\text { you. }\end{array}$ & $\begin{array}{l}\text { Don't do what } \\
\text { other people } \\
\text { think. }\end{array}$ \\
\hline $\begin{array}{l}\text { Take yourself for } \\
\text { better, for worse, as } \\
\text { your portion. }\end{array}$ & $\begin{array}{l}\text { Don't make } \\
\text { yourself do what } \\
\text { you don't want. }\end{array}$ \\
\hline $\begin{array}{l}\text { You must be } \\
\text { yourself and insist } \\
\text { yourself. }\end{array}$ & $\begin{array}{l}\text { Don't imitate } \\
\text { others. }\end{array}$ \\
\hline $\begin{array}{l}\text { You must leave the } \\
\text { church, for God is } \\
\text { everywhere. }\end{array}$ & $\begin{array}{l}\text { Don't rely on the } \\
\text { churches or the } \\
\text { priests. }\end{array}$ \\
\hline
\end{tabular}

Further, transcendentalism began to exist in American Romanticism. This movement was the reaction of the rationalism in the $18^{\text {th }}$ century. It later turned out as a manifestation of a growing trend in the $19^{\text {th }}$ century. It was a principle based on a belief of the unity of God and world. The transcendentalists certainly believe that each of the soul of individuals' was identically related to the world. Transcendentalism focused on the doctrine of Self-Reliance and individualism, which developed based on identification of the soul of individuals with God. This however, was closely tied 
to the theory of Romanticism, as it was pictured in Emerson's Self-Reliance.

The most obvious similarity between Transcendentalism and Romanticism was that both of them emphasized on 'self' which led to individualism. Individualism which has become an important identity of American nation began from the spirit of Self-Reliance. American nation believe in the power individualism. They believed that they could count on themselves. America was proud of being a powerful country. Based on the specific analysis and the broad discussion, the writer could finally infer that each individual has a power to do the best for himself. And this helped shape American character that we known today. Carbone II (2010) explained that luck and harmony can merely be reached if one could rely and trusted himself.

Emerson was also a transcendentalist. Most of the writers in this period tended to see themselves as lonely adventurers out of a crowd. They were very certain of the difference in individuals. This included the unique various ideas of each individual. The group of Romantic American Transcendentalists definitely increased individualism to the level of extremity.

The era of Romanticism was a part of the world's most important history. This revolutionizing movement has brought a new principle concept to American new generations particularly in literature. We can see how American people appreciated the hard work, the beauty of the nature, and individuals. They believed they can achieve something using their own efforts, ability and resources. They also admire the nature.

They really believed that human beings belong to the nature and must use the courage given by nature to gain the freedom, success, delight and prosperity. They also believed that no one can really give them happiness if they did not count themselves on seriously achieved the things they needed and desired for having a better future. By doing these, they believed they would grow to better and better. This was certainly the outcome of basic concepts of Romanticism.

In regard to that, a statement had been quoted from American Literature Tradition and Innovation (1969) saying that Emerson's basic doctrine exerted a profound influence on American thought. The basic idea on individualism was applied in every single aspect. This concept had brought a new vision towards every aspect of life, including economic, social, cultural, and political life in America. It was proven that his ideas certainly hada great impact on American life. The concept of Self-Reliance pointed out by Emerson had become an important key to open the new era of America. Tracing back to the beginning of the American history, the spirit of 'self' had actually already existed. The people from the Old World came to the New World in a great expectation. They considered themselves as the chosen people to build 'a city upon a hill'. This term was known as "American Dream" and has become the most important term in the history of America. People from the Old world carried the spirit and trusted that they would be able to do what god had informed them. They could count on themselves to sail, to survive in the ocean and to face the wild life and severe weather to reach the New World.

The power of 'self' had born a brand new spirit in the political system in America. The spirit of Democracy had adopted the principles of Self-Reliance. It supported the development of American nation. Individualism was hyperdeveloped in America (Abroad in America: Visitors to the New Nation 1776-1914). Everybody had a power and had been 
given a right to determine the best for himself. The use of the word "I" as many Americans use to show their attempts, was strongly adopted by the world 'self'. He was an independent individual that has 'self' to face his life and to hang on. This helped form the basic idea of democracy in America.

The spirit of 'self' was not only found in political life, but it was also found in the other important aspects of life, that was economic system. It was obviously seen in the development of economic life in America. The basic concept of selfReliance also appeared in American economic system. The individualism and the power of 'self' has fertilized the growth of American capitalist economic system. Capitalism was an economic system in which a country's businesses and industry were controlled and run for profit by private owners rather than by the government. Every individual was very optimistic and trust himself. His life was entirely based on his own hard work. This was indeed true. There was strong capitalism that centers on America as the impact of the basic idea of Self power and individualism.

\section{Conclusion}

Based on the data, information, and reliable sources obtained from careful library research with the Hall's theory of representation, there were some important points for the conclusion. It could be concluded that The Romanticism movement in America had practically changed the perception of Americans towards life, nature, self and God. The fundamental theory contained in American Romanticism was absolutely rekindled by the incredible Ralph Waldo Emerson in his fabulous, well-known and controversial essay Self-Reliance (1841). This influential writer and thinker also wrote many other critical and poems and essays during the period of Romanticism in America. It was precisely a great change in the world of literature. Many authors were then inspired by Emerson's literary works.

Further, Self-Reliance had helped shaped identity and uniqueness for American culture. It has also given an essential impact to American values such as good morality and independence in everyday life. As a result, it may lead people to have a better understanding of life and the power of 'self'. People began to realize it and believe that they could achieve or gain something if they trust their ability and do it by themselves. Emerson's spirit and his literary works had absolutely given a deep impact to American life, particularly, art, literature, society and religion.

\section{References}

Baym, N. et. al.(1989). The Norton anthology of American literature (vol 1). New York: Northon and Company.

Forsberg. N. (2019). From self-reliance to that which relies: Emerson and critique as self-criticism. Educational Philosophy and Theory Journal 51 (5): 498-507.

Capper, C. and D. A. Hollinger (2001) The American intellectual tradition. Oxford: Oxford University Press.

Carbone II, S.A. (2010). American transcendentalism and analysis of Ralph Waldo Emerson's "selfreliance." Inquiries Journal: Social, Scientific, Arts and Humanities, 2(1).

Hall, S. (Ed). (1997). The work of representation in representation: cultural representations and 
signifying practices. London: Sage Publications.

Hariwijaya, M and B. M. Djaelani (2004). Teknik menulis skripsi dan thesis. Yogyakarta: Zenith Publisher.

Liang, H. (2013). An eye for an "I"- An insight thought of self-reliance. Journal of Language Teaching and Research, 4 (6): 1351-1355.

Meserole, H. T., W. Sutton and B. Weber (1969). American literature tradition and innovation .The USA: Raytheon Eduaction Company.

Pachter, M. (1979). Abroad in America: Visitors to the new nation. The USA: Smithsonian Institution.

Pritchard, J. P. (1956). Criticism in America. Norman: University of Oklahoma Press.

Tocqueville, A. D. (1945). Democracy in America .Vintage Books: New York.

VanSpenckeren, K. (1994). Outline of American literature. The United States Department of States.

May, M. (2004). Absolute impact: drive for personal leadership. Mumbai: Jaico Publishing House. 